\title{
Preservative solutions on vase life and quality of cut Polianthes tuberosa L.
}

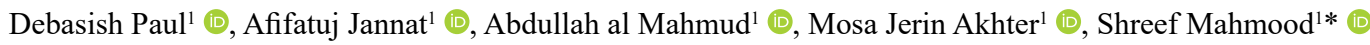 \\ ${ }^{1}$ Hajee Mohammad Danesh Science and Technology University, Department of Horticulture, Dinajpur, Bangladesh.
}

\begin{abstract}
This experiment was conducted to study the effectiveness of different preservative solutions on vase life and quality of angelica cut inflorescences cv. Single. The concentrations of citric acid at 100, 200 and $300 \mathrm{mg} \mathrm{L}^{-1}$, sucrose at $3 \%$ and $4 \%$ and $\mathrm{H}_{2} \mathrm{O}_{2}$ at $0.1 \%$, $0.2 \%$ and $0.3 \%$ were used as preservatives, while distilled water was used as control. The single factor experiment was laid out in a completely randomized design (CRD) with three replications. Citric acid and $\mathrm{H}_{2} \mathrm{O}_{2}$ solutions effectively inhibited bacterial growthrelated blockage in the vascular tissues, but had adverse effects on the vase life. The inflorescences stored in sucrose $(3 \%$ and $4 \%$ ) solutions remained fresh up to 10 days after preservation (DAP), maintaining good solution uptake, controlling transpiration loss and gaining higher relative fresh weight. Different quality parameters like floret diameter and number of opened florets were also significantly higher in inflorescences preserved in sucrose (3\% and 4\%) solution, followed by control, citric acid and $\mathrm{H}_{2} \mathrm{O}_{2}$, respectively, in different DAP. Overall, the inflorescence of cut tuberose preserved in sucrose, particularly at $4 \%$ solutions, showed better postharvest quality than other preservatives and maximum vase life.
\end{abstract}

Keywords: tuberose; sucrose; citric acid; hydrogen peroxide.

\section{RESUMO}

Soluções conservantes na vida de vaso e qualidade de Polianthes tuberosa $\mathrm{L}$. de corte

Este experimento foi conduzido para estudar a eficácia de diferentes soluções conservantes na vida de vaso e na qualidade de inflorescências de angélica de corte cv. Single. As concentrações de ácido cítrico a 100, 200 e $300 \mathrm{mg} \mathrm{L}^{-1}$, sacarose a $3 \%$ e $4 \% \mathrm{e}_{2} \mathrm{O}_{2}$ a $0,1 \%, 0,2 \%$ e $0,3 \%$ foram utilizadas como conservantes, enquanto a água destilada foi utilizada como controle. $\mathrm{O}$ experimento de fator único foi desenvolvido em um delineamento completamente randomizado (CRD), com três repetições. As soluções de ácido cítrico e $\mathrm{H}_{2} \mathrm{O}_{2}$ inibiram efetivamente o bloqueio relacionado ao crescimento bacteriano nos tecidos vasculares, mas tiveram efeitos adversos na vida de vaso. As inflorescências armazenadas em soluções de sacarose (3\% e 4\%) permaneceram frescas até 10 dias após a preservação (DAP), mantendo boa absorção da solução, controlando a perda de transpiração e ganhando maior massa fresca relativa. Diferentes parâmetros de qualidade, como o diâmetro do florete e o número de floretes abertos também foram significativamente superiores para as inflorescências preservadas em solução de sacarose (3\% e 4\%), seguida pelo controle, ácido cítrico e $\mathrm{H}_{2} \mathrm{O}_{2}$, respectivamente, em diferentes DAP. De maneira geral, as inflorescências de angélicas mantidas em sacarose, particularmente em soluções a 4\%, apresentaram melhor qualidade pós-colheita e maior vida de vaso em relação aos outros conservantes.

Palavras-chave: angélica; sacarose; ácido cítrico; peróxido de hidrogênio.

\section{INTRODUCTION}

Tuberose (Polianthes tuberosa L.) is a member of Agavaceae and its inflorescence (spike) bears 10-20 pairs of florets that open acropetally. It has long been cherished for the aromatic oils extracted from its fragrant white inflorescence, and has recently gained popularity as a cut flower. The fragrance of tuberoses comprises a blend of different volatile compounds (Babarabie et al., 2017), which have antimicrobial and antifungal properties and provide some health benefits against insomnia, influenza, and rheumatism (Rani and Singh, 2013). Tuberoses are mainly cultivated for the commercial production of their cut flowers, which constitutes a considerable portion of the floriculture business in Bangladesh. However, the vase life of cut tuberoses are usually short, and that reduces its quality

*Corresponding author: smahmood@hstu.ac.bd 
and commercial value during transportation, marketing and even at the customer level. Tuberose is sensitive to ethylene production, which results in the wilting and burning of florets and bending of the tips of flower spikes, as well as reduced vase life (Pérez-Arias et al., 2019).

In the floral industry, different preservative solutions are used to increase the vase life of cut flowers and keep them fresh for longer periods. Among these solutions, sucrose, which acts as a food source or respiratory substrate, delays the degradation of proteins and maintains the turgidity of expanding flower petals, is widely used (Rabiza-Świder et al., 2020). Several reports have shown that antibacterial compounds, like citric acid, are beneficial for decreasing $\mathrm{pH}$ of vase solutions, as well as the rate of bacterial growth, which is supposedly due to the reduction in vascular blockage (Van Doorn, 2012). In addition, a low concentration of hydrogen peroxide $\left(\mathrm{H}_{2} \mathrm{O}_{2}\right)$ could be used as a biocontrol agent to counter several abiotic and oxidative stresses during the postharvest time of fresh commodities (Herrera-Vásquez et al., 2015). It is necessary to compare the effectiveness of these preservative solutions in lengthening the vase life of cut tuberoses. Therefore, in the present research, the efficacy of sucrose, citric acid and hydrogen peroxide in extending the vase life of cut tuberoses cv. Single was evaluated.

\section{MATERIAL AND METHODS}

\section{Plant material}

The present work was undertaken in the laboratory of Horticulture, Hajee Mohammad Danesh Science and Technology University, Dinajpur, Bangladesh. The freshcut flowers of tuberose cv. Single came from the garden of Horticulture Centre, Department of Agricultural Extension, Dinajpur, Bangladesh. The flowers were harvested between 7:00 a.m. and 8:00 a.m., when two or three basal florets were open. The flowers were placed in cool water just after harvesting and transported to the laboratory. Afterwards, a $60 \mathrm{~cm}$ long stem was trimmed, and a smooth slanting cut was given to each cut stem, in order to facilitate the optimum uptake of the preservative solutions. The cut flowers were placed $7 \mathrm{~cm}$ under $300 \mathrm{~mL}$ preservative solution, in a $500 \mathrm{~mL}$ Erlenmeyer flask, and kept in ambient condition (temperature: $25 \pm 5^{\circ} \mathrm{C}$ and relative humidity: $60 \% \pm 5 \%$ ). The cut flowers were monitored throughout 2, 4, 6, 7, 8, 9 and 10 days after preservation (DAP).

\section{Treatments and experimental design}

The single factor experiment comprised of 8 treatments: distilled water (DW as control), 3 levels of citric acid (100, 200 and $300 \mathrm{mg} \mathrm{L}^{-1}$ citric acid solution), 2 levels of sucrose (3\% and $4 \%$ sucrose solution) and 3 levels of $\mathrm{H}_{2} \mathrm{O}_{2}$ $\left(0.1 \%, 0.2 \%\right.$ and $0.3 \% \mathrm{H}_{2} \mathrm{O}_{2}$ solution). The experiment was arranged in a completely randomized design (CRD), with three replications.

\section{Preparation of preservative solutions}

The citric acid (Merck, India) was weighed at 100, 200 and $300 \mathrm{mg}$, and each was dissolved into $1 \mathrm{~L} \mathrm{DW}$.
For $3 \%$ and $4 \%$ sucrose solution, 30 and $40 \mathrm{~g}$ of sucrose (Qualikems, India) were weighed, and each was put into $1 \mathrm{~L}$ of DW. The $30 \% \mathrm{H}_{2} \mathrm{O}_{2}$ (Merck, India) was pipetted at $3.33,6.67$ and $10 \mathrm{~mL}$, and each was diluted into 1 L DW. All the solutions were made just before the experimental setup.

\section{Solution uptake and transpiration loss}

Solution uptake was measured by the difference between consecutive weights of conical flask plus solution, and represented in $\mathrm{mL}$ (Ahmad et al., 2018), whereas transpiration loss of water of cut flower was recorded from the difference between consecutive weights of conical flask plus solution plus tuberose inflorescence, and expressed in $\mathrm{mL}$.

\section{Transpiration loss (mL) \\ $=$ Current weight of (conical flask + solution + tuberose inflorescence) \\ - Previous weight of (conical flask + solution + tuberose inflorescence)}

\section{Number and diameter of florets}

The number of opened florets and unopened floral buds per inflorescence was counted at DAP. Floret diameter was defined as the maximum diameter of each floret. It was measured from apex of two opposite florets by an electrical digital slide calliper (Guanglu, China), using the procedure of Wei et al. (2021).

\section{Changes of relative fresh weight}

The difference between the weight of Erlenmeyer flask with vase solutions (with flower) and the weight of Erlenmeyer flask with vase solution (without flower) were recorded at every alternate day interval to measure the fresh weight change of the flower during that particular time period. Changes of relative fresh weight were obtained by subtracting 100 from relative fresh weight (He et al., 2006), where $\mathrm{W}_{\mathrm{t}}=$ the weight of stem $(\mathrm{g})$ at $\mathrm{t}=2,4,6,7,8$, 9,10 DAP and $\mathrm{W}_{\mathrm{t}}=0$ is the weight of the same stem $(\mathrm{g})$ at initial day (Equation 1).

$$
\text { Changes of RFW }=\left(\frac{W_{t}}{W_{t=0}} \times 100\right)-100
$$

\section{Changes of $\mathrm{pH}$ and solution turbidity}

Solution turbidity attributable to microbial growth was assessed at 1, 4, 6, 7, and 10 DAP by measuring absorbance at $500 \mathrm{~nm}$ with a spectrophotometer (BK-UV1800 Vis Spectrophotometer, China), calculating the difference from the absorbance of respective preservation solution (Knee, 2000). Solution pH was determined using a $\mathrm{pH}$ meter (Hanna Instruments Model HI2211, Michigan, USA).

Vase life and anatomical sectioning of inflorescence

The vase life was determined as the number of days and it was considered as the period between harvest and 
the time when more than $50 \%$ of florets were wilted (Wei et al., 2021). Wilting symptoms were observed in the inflorescences of tuberoses after 6 DAP in $\mathrm{H}_{2} \mathrm{O}_{2}$, solutions and control and citric acid solutions after 7 DAP, and, for this reason, the results for these treatments are not presented in the tables. The anatomical sectioning of tuberose inflorescence was made and observed under a compound microscope (Uniteck Scientific \& Electronic Industry, India) with $(10 \times)$ magnification power by following the protocol of Park et al. (2017). The data was measured by observation on a scale of 15 , where $1 \leq 15 \%, 2=16 \%-30 \%$, $3=31 \%-45 \%, 4=46 \%-60 \%$ and $5>60 \%$ represent vascular blockage in the tuberose inflorescence xylem.

\section{Statistical analyses}

Statistical analysis of variance (ANOVA) was performed using the RStudio version 1.2.1335 statistical software (RStudio Team, 2019). The means were compared using Fisher's Least Significant Difference (LSD) test.

\section{RESULTS AND DISCUSSION}

\section{Solution uptake}

Solution uptake was significantly $(\mathrm{P}<0.05)$ influenced by different treatments at different DAP (Table 1). At the beginning of storage ( 2 and 4DAP), the flower sticks absorbed a comparatively higher amount of solution regardless of storage treatments. Means comparison indicated that aqueous solutions of sucrose ( $3 \%$ and $4 \%$ sucrose) had a more positive effect on increasing solution uptake than other preservative solutions. Initially, citric acid and $\mathrm{H}_{2} \mathrm{O}_{2}$ solutions performed better, but, after 4 DAP, the inflorescences preserved in these solutions were unmarketable due to high wilting symptoms. The preservative solutions containing $3 \%$ and $4 \%$ sucrose showed higher uptake of vase solution, because sucrose helps to maintain water balance and delays turgor loss. Kumar and Deen (2017) state that a high concentration of sucrose solutions enhanced higher solution uptake in tuberose cv. Hyderabad Double.

Table 1. Solution uptake of tuberose at different days after preservation.

\begin{tabular}{|c|c|c|c|c|c|c|c|}
\hline \multirow{2}{*}{ Treatment } & \multicolumn{7}{|c|}{ Solution uptake (mL) } \\
\hline & 2 DAP & 4 DAP & 6 DAP & 7 DAP & 8 DAP & 9 DAP & 10 DAP \\
\hline DW & $30.33 \mathrm{e}$ & $32.33 \mathrm{~b}$ & $11.33 \mathrm{~d}$ & $4.77 \mathrm{~d}$ & - & - & - \\
\hline $100 \mathrm{mg} \mathrm{L}^{-1} \mathrm{CA}$ & $31.33 \mathrm{de}$ & $33.67 \mathrm{~b}$ & $14.69 \mathrm{c}$ & $5.33 \mathrm{~d}$ & - & - & - \\
\hline $200 \mathrm{mg} \mathrm{L}^{-1} \mathrm{CA}$ & $33.71 \mathrm{bcd}$ & $41.33 \mathrm{a}$ & $16.12 b c$ & $6.68 \mathrm{c}$ & - & - & - \\
\hline $300 \mathrm{mg} \mathrm{L}^{-1} \mathrm{CA}$ & $35.67 \mathrm{abc}$ & $42.11 \mathrm{a}$ & $16.33 \mathrm{bc}$ & $8.47 \mathrm{~b}$ & - & - & - \\
\hline $3 \%$ Sucrose & $36.33 \mathrm{ab}$ & $43.15 \mathrm{a}$ & $18.12 \mathrm{~b}$ & $9.66 \mathrm{a}$ & $5.07 \mathrm{~b}$ & $3.85 \mathrm{~b}$ & $2.68 \mathrm{a}$ \\
\hline $4 \%$ Sucrose & $37.27 \mathrm{a}$ & $44.33 \mathrm{a}$ & $21.33 \mathrm{a}$ & $9.90 \mathrm{a}$ & $6.10 \mathrm{a}$ & $4.91 \mathrm{a}$ & $3.07 \mathrm{a}$ \\
\hline $0.1 \% \mathrm{H}_{2} \mathrm{O}_{2}$ & $33.67 \mathrm{bcd}$ & $41.23 \mathrm{a}$ & $15.67 \mathrm{bc}$ & $5.67 \mathrm{~cd}$ & - & - & - \\
\hline $0.2 \% \mathrm{H}_{2} \mathrm{O}_{2}$ & $34.95 \mathrm{abc}$ & $39.67 \mathrm{a}$ & $14.33 \mathrm{c}$ & - & - & - & - \\
\hline $0.3 \% \mathrm{H}_{2} \mathrm{O}_{2}$ & $32.67 \mathrm{cde}$ & $33.12 \mathrm{~b}$ & $11.67 \mathrm{~d}$ & - & - & - & - \\
\hline LSD (0.05) & 3.30 & 5.15 & 2.57 & 1.05 & 0.68 & 0.68 & 0.45 \\
\hline CV (\%) & 5.66 & 7.69 & 9.67 & 8.32 & 5.37 & 6.85 & 6.96 \\
\hline
\end{tabular}

DW: distilled water; CA: citric acid; LSD: least significant difference; CV: coefficient of variation; DAP: days after preservation.

\section{Transpiration loss}

Transpiration loss was increased during the experiment, however, the rate of transpiration loss was higher at 4 DAP, irrespective of storage treatments, and, afterwards, the rate declined over the storage period. Higher transpiration loss was recorded in control, citric acid (100 and $200 \mathrm{mg} \mathrm{L}^{-1}$ ) and $\mathrm{H}_{2} \mathrm{O}_{2}$ solutions at different DAP (Table 2). As a whole, sucrose solutions were found to be the best preservative solution in respect to transpiration loss, and, at the end of storage, lower transpiration loss was recorded at $4 \%$
$(6.33 \mathrm{~mL})$ compared to $3 \%(8.20 \mathrm{~mL})$ sucrose solution. From the present experiment, it is evident that sucrose solution is effective in controlling transpiration loss of cut tuberoses. Earlier, Aryal et al. (2019) observed that sucrose solution increased the vase life of roses by reducing transpiration loss and influencing water uptake. The high transpiration loss in the $\mathrm{H}_{2} \mathrm{O}_{2}$ solution might be due to higher chemical stress and/or shortage of carbohydrates in the solutions, resulting in quicker wilting in this treatment when compared to others. 
Table 2. Transpiration loss of tuberose at different days after preservation.

\begin{tabular}{|c|c|c|c|c|c|c|c|}
\hline \multirow{2}{*}{ Treatment } & \multicolumn{7}{|c|}{ Transpiration loss (mL) } \\
\hline & 2 DAP & 4 DAP & 6 DAP & 7 DAP & 8 DAP & 9 DAP & 10 DAP \\
\hline DW & $20.33 \mathrm{a}$ & $44.67 \mathrm{a}$ & $39.00 \mathrm{a}$ & $36.67 \mathrm{a}$ & - & - & - \\
\hline $100 \mathrm{mg} \mathrm{L}^{-1} \mathrm{CA}$ & $19.67 \mathrm{ab}$ & $42.67 \mathrm{ab}$ & $38.33 \mathrm{a}$ & $36.33 \mathrm{a}$ & - & - & - \\
\hline $200 \mathrm{mg} \mathrm{L}^{-1} \mathrm{CA}$ & $17.33 \mathrm{bc}$ & $39.00 \mathrm{bc}$ & $36.33 \mathrm{abc}$ & $35.33 \mathrm{ab}$ & - & - & - \\
\hline $300 \mathrm{mg} \mathrm{L}^{-1} \mathrm{CA}$ & $17.36 \mathrm{bc}$ & $38.00 \mathrm{c}$ & $34.67 \mathrm{bc}$ & $32.33 \mathrm{~b}$ & - & - & - \\
\hline $3 \%$ Sucrose & $17.00 \mathrm{c}$ & $37.00 \mathrm{c}$ & $34.67 \mathrm{c}$ & $32.33 \mathrm{~b}$ & $26.67 \mathrm{a}$ & $11.67 \mathrm{a}$ & $8.20 \mathrm{a}$ \\
\hline $4 \%$ Sucrose & $16.67 \mathrm{c}$ & $36.67 \mathrm{c}$ & $34.33 \mathrm{c}$ & $31.67 \mathrm{~b}$ & $23.70 \mathrm{a}$ & $10.33 \mathrm{a}$ & $6.33 \mathrm{~b}$ \\
\hline $0.1 \% \mathrm{H}_{2} \mathrm{O}_{2}$ & $18.33 \mathrm{abc}$ & $39.67 \mathrm{bc}$ & $37.38 \mathrm{abc}$ & $34.67 \mathrm{ab}$ & - & - & - \\
\hline $0.2 \% \mathrm{H}_{2} \mathrm{O}_{2}$ & $18.67 \mathrm{abc}$ & $41.00 \mathrm{abc}$ & $37.58 \mathrm{ab}$ & - & - & - & - \\
\hline $0.3 \% \mathrm{H}_{2} \mathrm{O}_{2}$ & 20.33 a & $41.00 \mathrm{abc}$ & $37.67 \mathrm{ab}$ & - & - & - & - \\
\hline LSD & 2.48 & 4.63 & 3.13 & 3.15 & 3.52 & 1.59 & 1.30 \\
\hline CV (\%) & 7.85 & 6.76 & 4.98 & 6.23 & 6.16 & 6.36 & 7.87 \\
\hline
\end{tabular}

DW: distilled water; CA: citric acid; LSD: least significant difference; CV: coefficient of variation; DAP: days after preservation.

\section{Diameter of floret}

The size of floret has always been one of the most important morphological indicators of cut tuberoses. In general, the diameter of the floret was increased, and, afterwards, decreased on the progress of the storage period. Initially, the highest diameter of floret was measured in citric acid and sucrose treatments. At the end of storage, flowers preserved in sucrose solutions had the highest diameter of floret compared to other treatments (Table 3). Initially, citric acid maintained a higher diameter of floret, which could be due to the fact that this chemical reduced bacterial growth and prevented vascular blockages, but, later on, could not supply respiratory substrates for the opening florets. Similar results had been recorded by Kumari et al. (2018) in cut tuberose cv. Calcutta Single. Overall sucrose (3\% and $4 \%$ ) solution performed better to maintain the diameter of floret, as this solution provided adequate food sources or carbohydrates, resulting in higher floral diameter.

Table 3. Floret diameter of a particular tuberose floret at different days after preservation.

\begin{tabular}{|c|c|c|c|c|c|c|c|}
\hline \multirow{2}{*}{ Treatment } & \multicolumn{7}{|c|}{ Floret diameter (mm) } \\
\hline & 2 DAP & 4 DAP & 6 DAP & 7 DAP & 8 DAP & 9 DAP & 10 DAP \\
\hline DW & $16.79 \mathrm{bc}$ & $32.21 \mathrm{ab}$ & 22.89 def & $16.58 \mathrm{~d}$ & - & - & - \\
\hline $100 \mathrm{mg} \mathrm{L}^{-1} \mathrm{CA}$ & $19.94 \mathrm{a}$ & $33.11 \mathrm{a}$ & $23.77 \mathrm{de}$ & $17.71 \mathrm{~cd}$ & - & - & - \\
\hline $200 \mathrm{mg} \mathrm{L}^{-1} \mathrm{CA}$ & $18.98 \mathrm{a}$ & $33.55 \mathrm{a}$ & $24.49 \mathrm{~d}$ & $19.87 \mathrm{c}$ & - & - & - \\
\hline $300 \mathrm{mg} \mathrm{L}^{-1} \mathrm{CA}$ & $18.37 \mathrm{ab}$ & $34.34 \mathrm{a}$ & $28.58 \mathrm{c}$ & $25.85 \mathrm{~b}$ & - & - & - \\
\hline $3 \%$ Sucrose & $18.50 \mathrm{ab}$ & $28.21 \mathrm{bc}$ & $35.46 \mathrm{~b}$ & $32.86 \mathrm{a}$ & $28.40 \mathrm{a}$ & $25.23 \mathrm{a}$ & $22.37 \mathrm{a}$ \\
\hline $4 \%$ Sucrose & $18.57 \mathrm{a}$ & $28.20 \mathrm{bc}$ & $38.43 \mathrm{a}$ & $35.60 \mathrm{a}$ & $31.61 \mathrm{a}$ & $28.48 \mathrm{a}$ & $25.35 \mathrm{a}$ \\
\hline $0.1 \% \mathrm{H}_{2} \mathrm{O}_{2}$ & $15.41 \mathrm{c}$ & $33.31 \mathrm{a}$ & 21.13 ef & $15.18 \mathrm{~d}$ & - & - & - \\
\hline $0.2 \% \mathrm{H}_{2} \mathrm{O}_{2}$ & $15.37 \mathrm{c}$ & $31.79 \mathrm{ab}$ & $20.21 \mathrm{f}$ & - & - & - & - \\
\hline $0.3 \% \mathrm{H}_{2} \mathrm{O}_{2}$ & $12.65 \mathrm{~d}$ & $27.41 \mathrm{c}$ & $15.48 \mathrm{~g}$ & - & - & - & - \\
\hline LSD & 1.72 & 4.12 & 2.90 & 3.29 & 4.53 & 5.78 & 5.13 \\
\hline $\mathrm{CV}(\%)$ & 5.82 & 7.66 & 6.60 & 8.05 & 6.67 & 9.49 & 9.49 \\
\hline
\end{tabular}

DW: distilled water; CA: citric acid; LSD: least significant difference; CV: coefficient of variation; DAP: days after preservation.

\section{Number of opened and unopened florets per inflorescence}

The number of opened florets increased significantly from 2 DAP, and reached a maximum number of opened florets at 4 DAP, regardless of preservative solution.
Afterwards, the number of opened florets decreased with the advancement of vase life; however, the decreasing rate was comparatively slower in sucrose solutions (Table 4). On the contrary, the highest number of unopened florets was counted in control and $\mathrm{H}_{2} \mathrm{O}_{2}$ solutions compared to 
other storage treatments. In this study, sucrose solutions promoted the opening of the floret of the tuberoses because flower buds require carbohydrates to open, and, without sucrose, florets failed to open naturally. Sucrose provides essential substrate for respiration, structural material and carbon skeletons for bud opening (Rabiza-Świder et al., 2020). The maximum number of unopened flower buds per inflorescence in other treatments may be due to the fact that adequate moisture alone could not assist to open florets. Overall sucrose ( $3 \%$ and $4 \%$ ) solution performed better to maintain the diameter of florets, as this solution provided adequate food sources or carbohydrates, resulting in higher floral diameter. Similar improvement was reported by Kumari et al. (2018) in the opening of florets with high sucrose concentration in cut tuberose cv. Calcutta Single.

Table 4. Number of opened florets at different days after preservation and unopened buds of tuberose at the end of vase life.

\begin{tabular}{|c|c|c|c|c|c|c|c|c|}
\hline \multirow{2}{*}{ Treatment } & \multicolumn{7}{|c|}{ Number of opened florets } & \multirow{2}{*}{$\begin{array}{l}\text { Unopened } \\
\text { buds }\end{array}$} \\
\hline & 2 DAP & 4 DAP & 6 DAP & 7DAP & 8 DAP & 9 DAP & 10 DAP & \\
\hline DW & $1.23 \mathrm{~d}$ & $4.83 \mathrm{~b}$ & $1.33 \mathrm{f}$ & $1.22 \mathrm{~d}$ & - & - & - & $27.29 \mathrm{a}$ \\
\hline $100 \mathrm{mg} \mathrm{L}^{-1} \mathrm{CA}$ & $1.20 \mathrm{~d}$ & $5.63 \mathrm{a}$ & $1.33 \mathrm{f}$ & $1.23 \mathrm{~d}$ & - & - & - & $25.47 \mathrm{ab}$ \\
\hline $200 \mathrm{mg} \mathrm{L}^{-1} \mathrm{CA}$ & $1.34 \mathrm{c}$ & $5.94 \mathrm{a}$ & $1.43 \mathrm{f}$ & $1.43 \mathrm{~cd}$ & - & - & - & $21.67 \mathrm{c}$ \\
\hline $300 \mathrm{mg} \mathrm{L}^{-1} \mathrm{CA}$ & $1.47 \mathrm{bc}$ & $5.93 \mathrm{a}$ & $2.67 \mathrm{c}$ & $1.56 \mathrm{c}$ & - & - & - & $22.33 \mathrm{bc}$ \\
\hline $3 \%$ Sucrose & $1.85 \mathrm{a}$ & $5.42 \mathrm{a}$ & $3.17 \mathrm{~b}$ & $2.00 \mathrm{~b}$ & $2.10 \mathrm{~b}$ & $1.87 \mathrm{~b}$ & $1.36 \mathrm{a}$ & $14.67 \mathrm{~d}$ \\
\hline $4 \%$ Sucrose & $1.57 \mathrm{~b}$ & $5.49 \mathrm{a}$ & $3.79 \mathrm{a}$ & $2.67 \mathrm{a}$ & $2.67 \mathrm{a}$ & $2.23 \mathrm{a}$ & $1.45 \mathrm{a}$ & $16.00 \mathrm{~d}$ \\
\hline $0.1 \% \mathrm{H}_{2} \mathrm{O}_{2}$ & $1.32 \mathrm{c}$ & $4.59 \mathrm{~b}$ & $3.24 \mathrm{~b}$ & $1.59 \mathrm{c}$ & - & - & - & $25.34 \mathrm{ab}$ \\
\hline $0.2 \% \mathrm{H}_{2} \mathrm{O}_{2}$ & $1.23 \mathrm{~d}$ & $4.35 \mathrm{~b}$ & $2.23 d$ & - & - & - & - & $26.67 \mathrm{a}$ \\
\hline $0.3 \% \mathrm{H}_{2} \mathrm{O}_{2}$ & $1.21 \mathrm{~d}$ & $4.26 \mathrm{~b}$ & $1.89 \mathrm{e}$ & - & - & - & - & $27.67 \mathrm{a}$ \\
\hline LSD & 0.19 & 0.58 & 0.31 & 0.28 & 0.45 & 0.45 & 0.17 & 3.43 \\
\hline CV (\%) & 8.04 & 6.60 & 7.69 & 9.57 & 8.39 & 9.77 & 5.33 & 8.69 \\
\hline
\end{tabular}

DW: distilled water; CA: citric acid; LSD: least significant difference; CV: coefficient of variation; DAP: days after preservation.

\section{Changes of relative fresh weight}

In general, the inflorescence of tuberose gained relative fresh weight up to 4 DAP; afterwards, the inflorescence lost their fresh weight with the progress of vase life, regardless of storage treatments. Despite relatively low losses of fresh weight from 6 to 10 DAP, sucrose-containing solutions had the highest fresh weight compared to other treatments, and, particularly, 4\% sucrose solution was the most effective treatment (Table 5). The present result showed that the highest fresh weight was obtained by sucrose solution, as it provided carbohydrates, enhanced solution uptake and controlled transpiration losses of the tuberose inflorescences. A recent study with cut roses by Kshirsagar et al. (2021) noted similar results: $2 \%$ sucrose solution increased the fresh weight of the flower as it enhanced the quality of rose by reducing the respiration and transpiration rate.

Table 5. Changes of relative fresh weight (\%) of tuberose inflorescence at different days after preservation.

\begin{tabular}{|c|c|c|c|c|c|c|c|}
\hline \multirow{2}{*}{ Treatment } & \multicolumn{7}{|c|}{ Changes of relative fresh weight $(\%)$} \\
\hline & 2 DAP & 4 DAP & 6 DAP & 7 DAP & 8 DAP & 9 DAP & 10 DAP \\
\hline DW & $4.66 \mathrm{~d}$ & $3.06 \mathrm{~d}$ & $-12.20 \mathrm{~g}$ & $-26.44 \mathrm{e}$ & - & - & - \\
\hline $100 \mathrm{mg} \mathrm{L}^{-1} \mathrm{CA}$ & $5.77 \mathrm{c}$ & $3.86 \mathrm{c}$ & $-10.51 \mathrm{fg}$ & $-24.78 \mathrm{de}$ & - & - & - \\
\hline $200 \mathrm{mg} \mathrm{L}^{-1} \mathrm{CA}$ & $6.07 \mathrm{bc}$ & $6.37 \mathrm{~b}$ & $-6.24 c$ & $-21.00 \mathrm{~cd}$ & - & - & - \\
\hline $300 \mathrm{mg} \mathrm{L}^{-1} \mathrm{CA}$ & $6.11 \mathrm{bc}$ & $6.83 \mathrm{~b}$ & $-5.93 c$ & $-19.49 a b$ & - & - & - \\
\hline $3 \%$ Sucrose & $6.90 \mathrm{ab}$ & $7.86 \mathrm{a}$ & $-5.23 b$ & $-19.55 b c$ & $-31.63 \mathrm{a}$ & $-37.78 b$ & $-42.16 b$ \\
\hline $4 \%$ Sucrose & $7.06 \mathrm{a}$ & $8.06 \mathrm{a}$ & $-4.94 \mathrm{a}$ & $-17.39 a$ & $-27.51 \mathrm{a}$ & $-32.88 \mathrm{a}$ & $-34.70 a$ \\
\hline $0.1 \% \mathrm{H}_{2} \mathrm{O}_{2}$ & $5.83 \mathrm{c}$ & $3.82 \mathrm{c}$ & $-7.03 d$ & $-23.28 \mathrm{de}$ & - & - & - \\
\hline $0.2 \% \mathrm{H}_{2} \mathrm{O}_{2}$ & $5.55 \mathrm{c}$ & $3.63 \mathrm{~cd}$ & -8.42 de & - & - & - & - \\
\hline $0.3 \% \mathrm{H}_{2} \mathrm{O}_{2}$ & $5.50 \mathrm{~cd}$ & $3.31 \mathrm{~cd}$ & -9.06 ef & - & - & - & - \\
\hline LSD & 0.86 & 0.74 & 0.94 & 2.54 & 4.76 & 5.67 & 9.07 \\
\hline CV (\%) & 8.42 & 8.33 & 7.12 & 6.67 & 7.10 & 7.07 & 10.41 \\
\hline
\end{tabular}

DW: distilled water; CA: citric acid; LSD: least significant difference; CV: coefficient of variation; DAP: days after preservation. 


\section{Changes in solution turbidity}

In general, the value of solution turbidity was initially low, and, afterwards, increased gradually with the preservation period. Minimum changes in solution turbidity (absorbance) were recorded both in the citric acid and $\mathrm{H}_{2} \mathrm{O}_{2}$ solutions, whereas both sucrose and control solutions had relatively higher changes of turbidity at different DAP (Table 6). The higher absorbance value of sucrose and control solutions indicated a higher number of pathogens in these solutions.
Although sucrose solution enhances bacterial multiplication in the preservative solution, it also supplies carbohydrates to cut flowers and increases its vase life (Gebremedhin et al., 2013). On the contrary, citric acid and $\mathrm{H}_{2} \mathrm{O}_{2}$ solutions had minimum changes in absorbance in all cases, indicating this solution limits bacterial growth by lowering the $\mathrm{pH}$ level of the solutions. Van Doorn (2012) and Liao et al. (2012) reported that citric acid acted as a $\mathrm{pH}$ regulator that reduced bacterial proliferation in the preservative solutions.

Table 6. Changes in solution turbidity of preservative solutions at different days after preservation.

\begin{tabular}{|c|c|c|c|c|}
\hline \multirow{2}{*}{ Treatment } & \multicolumn{4}{|c|}{ Changes in solution turbidity (absorbance) } \\
\hline & 4 DAP & 6 DAP & 7 DAP & 10 DAP \\
\hline DW & $0.018 \mathrm{~b}$ & $0.022 \mathrm{c}$ & $0.029 \mathrm{~b}$ & - \\
\hline $100 \mathrm{mg} \mathrm{L}^{-1} \mathrm{CA}$ & $0.012 \mathrm{~b}$ & $0.020 \mathrm{c}$ & $0.026 \mathrm{~b}$ & - \\
\hline $200 \mathrm{mg} \mathrm{L}^{-1} \mathrm{CA}$ & $0.010 \mathrm{~cd}$ & $0.013 \mathrm{~d}$ & $0.017 \mathrm{~cd}$ & - \\
\hline $300 \mathrm{mg} \mathrm{L}^{-1} \mathrm{CA}$ & $0.008 \mathrm{de}$ & $0.008 \mathrm{e}$ & $0.015 \mathrm{~d}$ & - \\
\hline $3 \%$ Sucrose & $0.019 \mathrm{~b}$ & $0.025 \mathrm{~b}$ & $0.030 \mathrm{~b}$ & $0.035 \mathrm{~b}$ \\
\hline $4 \%$ Sucrose & $0.022 \mathrm{a}$ & $0.030 \mathrm{a}$ & $0.036 \mathrm{a}$ & $0.041 \mathrm{a}$ \\
\hline $0.1 \% \mathrm{H}_{2} \mathrm{O}_{2}$ & 0.007 ef & $0.014 \mathrm{~d}$ & $0.020 \mathrm{c}$ & - \\
\hline $0.2 \% \mathrm{H}_{2} \mathrm{O}_{2}$ & 0.007 ef & $0.009 \mathrm{e}$ & - & - \\
\hline $0.3 \% \mathrm{H}_{2} \mathrm{O}_{2}$ & $0.005 \mathrm{f}$ & $0.007 \mathrm{e}$ & - & - \\
\hline LSD & 0.003 & 0.003 & 0.005 & 0.006 \\
\hline CV (\%) & 13.608 & 9.289 & 10.596 & 6.709 \\
\hline
\end{tabular}

DW: distilled water; CA: citric acid; LSD: least significant difference; CV: coefficient of variation; DAP: days after preservation.

\section{Changes in pH}

Freshly prepared citric acid solutions (100, 200 and 300 $\mathrm{mg} \mathrm{L}^{-1}$ ) had comparatively lower $\mathrm{pH}$ than other preservative solutions, as they released more $\mathrm{H}^{+}$in the solution (Table 7). The freshly prepared sucrose and $\mathrm{H}_{2} \mathrm{O}_{2}$ containing solutions had $\mathrm{pH}$ near neutral. However, minimum changes in $\mathrm{pH}$ were detected in different DAP, and $\mathrm{pH}$ value was increased over the storage period, irrespective of treatments. The increasing trend of $\mathrm{pH}$ during vase life might be associated with the higher multiplication of microorganisms in the solution, transport physiology and metabolism of cut flower; similar results were also noted by Shanan (2017) in Rosa hybrida cv Teresa.

Table 7. $\mathrm{pH}$ of preservative solution at different days after preservation.

\begin{tabular}{|c|c|c|c|c|c|}
\hline \multirow{2}{*}{ Treatment } & \multicolumn{5}{|c|}{ pH } \\
\hline & Initial & 5 DAP & 6 DAP & 7 DAP & 10 DAP \\
\hline DW & $7.16 \mathrm{a}$ & $6.89 \mathrm{a}$ & $7.24 \mathrm{a}$ & $7.28 \mathrm{a}$ & - \\
\hline $100 \mathrm{mg} \mathrm{L}^{-1} \mathrm{CA}$ & $5.72 b$ & $5.81 \mathrm{~b}$ & $5.88 \mathrm{~b}$ & $5.92 \mathrm{~b}$ & - \\
\hline $200 \mathrm{mg} \mathrm{L}^{-1} \mathrm{CA}$ & $4.70 \mathrm{c}$ & $4.79 \mathrm{c}$ & $4.81 \mathrm{c}$ & $4.83 \mathrm{c}$ & - \\
\hline $300 \mathrm{mg} \mathrm{L}^{-1} \mathrm{CA}$ & $4.24 \mathrm{c}$ & $4.19 \mathrm{c}$ & $4.23 \mathrm{c}$ & $4.25 \mathrm{c}$ & - \\
\hline $3 \%$ Sucrose & $7.17 \mathrm{a}$ & $7.23 \mathrm{a}$ & $7.28 \mathrm{a}$ & $7.32 \mathrm{a}$ & $7.42 \mathrm{a}$ \\
\hline $4 \%$ Sucrose & $7.16 \mathrm{a}$ & $6.93 \mathrm{a}$ & $7.29 \mathrm{a}$ & $7.34 \mathrm{a}$ & $7.43 \mathrm{a}$ \\
\hline $0.1 \% \mathrm{H}_{2} \mathrm{O}_{2}$ & $7.16 \mathrm{a}$ & $7.21 \mathrm{a}$ & $7.22 \mathrm{a}$ & $7.25 \mathrm{a}$ & - \\
\hline $0.2 \% \mathrm{H}_{2} \mathrm{O}_{2}$ & $6.89 \mathrm{a}$ & $7.18 \mathrm{a}$ & $7.21 \mathrm{a}$ & - & - \\
\hline $0.3 \% \mathrm{H}_{2} \mathrm{O}_{2}$ & $6.89 \mathrm{a}$ & $7.17 \mathrm{a}$ & $7.18 \mathrm{a}$ & - & - \\
\hline LSD & 0.61 & 0.79 & 0.94 & 0.70 & 0.79 \\
\hline CV (\%) & 5.56 & 7.24 & 8.48 & 6.34 & 8.78 \\
\hline
\end{tabular}

DW: distilled water; CA: citric acid; LSD: least significant difference; CV: coefficient of variation; DAP: days after preservation. 


\section{Vase life}

Different preservative solutions had a significant effect $(\mathrm{P}<0.05)$ on the vase life of tuberose. Vase life of cut tuberoses was extended by $3 \%$ and $4 \%$ sucrose solution up to 10 days when compared to control and citric acid solutions ( 7 days), while $\mathrm{H}_{2} \mathrm{O}_{2}$ solution $(0.2 \%$ and $0.3 \%)$ shortened the vase life to 6 days only (Table 8). $\mathrm{H}_{2} \mathrm{O}_{2}$ treatments at all concentrations caused low water uptake, high transpiration loss and accelerated floret abscission. Increasing concentration of sucrose markedly delayed senescence and increased the vase life of cut tuberoses, which might be due to the supply of respiratory substrate for the maintenance of osmotic potential. Singh et al. (2018) also reported that $4 \%$ sucrose solution increased the vase life of tuberose significantly, as the peroxidase activity was the lowest. However, there were no significant differences in vase life between citric acid and control treatments.

Table 8. Effect of different preservative solutions on vase life of tuberose.

\begin{tabular}{|l|c|c|}
\hline Treatment & Vase life (days) & Blockage level* \\
\hline $\mathrm{DW}$ & $7.13 \mathrm{bcd}$ & $3.33 \mathrm{bc}$ \\
\hline $100 \mathrm{mg} \mathrm{L}^{-1} \mathrm{CA}$ & $7.22 \mathrm{bc}$ & $3.33 \mathrm{bc}$ \\
\hline $200 \mathrm{mg} \mathrm{L}^{-1} \mathrm{CA}$ & $7.38 \mathrm{~b}$ & $2.33 \mathrm{~d}$ \\
\hline $300 \mathrm{mg} \mathrm{L}^{-1} \mathrm{CA}$ & $7.44 \mathrm{~b}$ & $2.33 \mathrm{~d}$ \\
\hline $3 \%$ Sucrose & $10.20 \mathrm{a}$ & $3.67 \mathrm{ab}$ \\
\hline $4 \% \mathrm{Sucrose}^{*}$ & $10.34 \mathrm{a}$ & $4.33 \mathrm{a}$ \\
\hline $0.1 \% \mathrm{H}_{2} \mathrm{O}_{2}$ & $7.22 \mathrm{bc}$ & $2.67 \mathrm{~cd}$ \\
\hline $0.2 \% \mathrm{H}_{2} \mathrm{O}_{2}$ & $6.22 \mathrm{~cd}$ & $2.33 \mathrm{~d}$ \\
\hline $0.3 \% \mathrm{H}_{2} \mathrm{O}_{2}$ & $6.11 \mathrm{~d}$ & $2.00 \mathrm{~d}$ \\
\hline $\mathrm{LSD}$ & 1.03 & 0.93 \\
\hline $\mathrm{CV}(\%)$ & 7.80 & 18.60 \\
\hline
\end{tabular}

*Based on a scale of $1-5$, where $1 \% \leq 15 \%, 2=16 \%-30 \%, 3=31 \%-45 \%$, $4=46 \%-60 \%, 5>60 \%$ represent vascular blockage; DW: distilled water; CA: citric acid; LSD: least significant difference; $\mathrm{CV}$ : coefficient of variation.

\section{Anatomical sectioning of inflorescence}

After transverse sectioning of inflorescence, the data on blockage in xylem was 4.33 and 3.67 , observed in the section of inflorescence which was kept in $3 \%$ and $4 \%$ sucrose solution respectively, which might be due to the deposition of sugars or/and microbial growth in the xylem (Table 8). A recent study on carnation cv. Edun also found that sucrose promoted the growth of blockage in xylem vessels, as sucrose encourages bacterial growth both in the vase solution and in the vascular tissue, which impeded water uptake by flower stems and caused wilting or senescence (Park et al., 2017). Despite xylem blockage, sucrose solution provided essential carbohydrates to the inflorescence of tuberose, which, ultimately, enhanced the vase life of the cut flower. On the contrary, inflorescence in citric acid and $\mathrm{H}_{2} \mathrm{O}_{2}$ solution showed less xylem blockage, as it prevented microbial growth in the xylem. Van Doorn (2012) reported similar results: citric acid reduced bacterial proliferation and enhanced water conductance in xylem of cut flowers.

\section{CONCLUSIONS}

Vase life and quality of cut tuberoses were associated with their efficient ability of water uptake and control of transpiration loss, as well as their capacity to protect themselves against pathogens. Although citric acid and $\mathrm{H}_{2} \mathrm{O}_{2}$ solutions showed a great effect on inhibition of bacterial growth-related blockage in the vascular tissues of inflorescence, limited food sources or respiratory substrates decreased the vase life and quality of cut tuberoses. In conclusion, sucrose, particularly at 4\% solution, effectively improved the quality parameters in most of the cases, which, ultimately, increased the vase life and quality of cut tuberose cv. Single.

\section{AUTHOR CONTRIBUTION}

This work was carried out in collaboration among all authors. Authors DP and SM designed the study, performed the statistical analysis and wrote the first draft of the manuscript. Authors AJ, AAM and JA edited the manuscript. All authors read and approved the final manuscript.

\section{ACKNOWLEDGEMENTS}

The authors express their appreciation to the Bangladesh's Ministry of Science and Technology (MOST) for the financial support of the research project.

\section{REFERENCES}

AHMAD, I.; ABBAS, S.M.; ASIF, M.; DOLE, J.M.; SHAFIQUE, M.U.; QASIM, M. Optimal storage protocols for cut Narcissus tazetta and Polianthes tuberosa stems. Scientia Horticulturae, v.229, p.40-44, 2018. https://doi. org/10.1016/j.scienta.2017.10.022

ARYAL, P.; ADHIKARI, A.; PATHAK, R.; PUDASAINI, R. Effects of different concentrations of sucrose and citric acid on vase life of rose. Journal of Agriculture and Natural Resources, v.2, n.1, p.127-134, 2019. https://doi. org/10.3126/janr.v2i1.26053

BABARABIE, M.; SHAHI, Z.G.G.; ZAREI, H.; DANYAEI, A. Physiological response of tuberose cut flowers to the benzyladenine and plant extracts. Advances in Bioresearch, v.8, n.2, p.81-89, 2017. http://dx.doi. org/10.15515/abr.0976-4585.8.2.8189

GEBREMEDHIN, H.; TESFAYE, B.; MOHAMMED, A.; TSEGAY, D. Influence of preservative solutions on vase life and postharvest characteristics of rose (Rosa hybrid) cut flowers. International Journal of Biotechnology and Molecular Biology Research, v.4, n.8, p.111-118, 2013. http://dx.doi.org/10.5897/IJBMBR2013.0171 
HERRERA-VÁSQUEZ, A.; SALINAS, P.; HOLUIGUE, L. Salicylic acid and reactive oxygen species interplay in the transcriptional control of defense genes expression. Frontiers in Plant Science, v.6, p.171, 2015. https://doi. org/10.3389/fpls.2015.00171

HE, S.; JOYCE, D.C.; IRVING, D.E.; FARAGHER, J.D. Stem end blockage in cut Grevillea "Crimson Yul-lo" inflorescences. Postharvest Biology and Technology, v.41, n.1, p.78-84, 2006. https://doi.org/10.1016/j.postharvbio.2006.03.002

KNEE, M. Selection of biocides for use in floral preservatives. Postharvest Biology and Technology, v.18, n.3, p.227-234, 2000. https://doi.org/10.1016/S0925-5214(99)00074-5

KSHIRSAGAR, S.; KUMAR, A.; SINGH, O.; GALLANI, R.; PARMAR, R. Effect of postharvest preservatives on vase life of cut rose (Rosa hybrida L.) cv. Top secret. Journal of Pharmacognosy and Phytochemistry, v.10, n.1, p.1056-1061, 2021.

KUMAR, A.; DEEN, B. Effect of eco-friendly vase solution on maximum buds opening and longer vase-life of tuberose (Polianthes tuberosa L.) cv. Hyderabad Double. Journal of Pharmacognosy and Phytochemistry, v.6, n.4, p.1233-1236, 2017.

KUMARI, S.; BABU, R.; SARIKA, K.; DEB, P. Effect of different preservatives on vase-life of cut tuberose (Polianthes tuberosa L.) cv. Calcultta Single. International Journal of Current Microbiology and Applied Sciences, v.7, n.1, p.16511657, 2018. http://dx.doi.org/10.20546/ijcmas.2018.701.200

LIAO, W.B.; ZHANG, M.L.; HUANG, G.B.; YU, J.H. Hydrogen peroxide in the vase solution increases vase life and keeping quality of cut Oriental $\times$ Trumpet hybrid lily "Manissa". Scientia Horticulturae, v.139, p.32-38, 2012. https://doi.org/10.1016/j.scienta.2012.02.040

PARK, D.Y.; NAING, A.H.; AI, T.N.; HAN, J.S.; KANG, I.K.; KIM, C.K. Synergistic effect of nano-sliver with sucrose on extending vase life of the carnation cv. Edun. Frontiers in Plant Science, v.8, p.1601, 2017. https:// dx.doi.org/10.3389\%2Ffpls.2017.01601
PÉREZ-ARIAS, G.A.; ALIA-TEJACAL, I.; COLINASLEÓN, M.T.; VALDEZ-AGUILAR, L.A.; PELAYOZALDÍVAR, C. Postharvest physiology and technology of the tuberose (Polianthes tuberosa L.): an ornamental flower native to Mexico. Horticulture Environment and Biotechnology, v.60, n.3, p.281-293, 2019. https://doi. org/10.1007/s13580-018-00122-4

SHANAN, N. Optimum $\mathrm{pH}$ value for improving postharvest characteristics and extending vase life of Rosa hybrida cv. Tereasa Cut Flowers. Asian Journal of Advances in Agricultural Research, v.1, n.3, p.1-11, 2017.https://doi. org/10.9734/AJAAR/2017/34655

RABIZA-ŚWIDER, J.; SKUTNIK, E.; JĘDRZEJUK, A.; ROCHALA-WOJCIECHOWSKA, J. Nanosilver and sucrose delay the senescence of cut snapdragon flowers. Postharvest Biology and Technology, v.165, 111165, 2020. https://doi.org/10.1016/j.postharvbio.2020.111165

RANI, P.; SINGH, N. Impact of gibberellic acid pretreatment on growth and flowering of tuberose (Polianthes tuberosa L.) cv. Prajwal. Journal of Tropical Plant Physiology, v.5, p.33-42, 2013.

RSTUDIO TEAM. RStudio: integrated development for R. RStudio.Inc., Boston: R. RStudio. Inc, 2019. Available in: $<$ http://www.rstudio.com/> Accessed on: Apr 2020.

SINGH, K.P.; SINGH, B.; RAM, D.; THAKUR, D.S.; AYAM, G.P. Standardization of floral preservatives affecting the enzyme activity in petals of tuberose spikes. Journal of Pure and Applied Microbiology, v.11, n.3, p.1573-1576, 2018. http://dx.doi.org/10.22207/JPAM.11.3.43

VAN DOORN, W.G. Water relations of cut flowers: an update. Horticultural Reviews, v.40, n.1, p.55-106, 2012. https://doi.org/10.1002/9781118351871.ch2

WEI, L.; WANG, C.; LIAO, W. Hydrogen sulfide improves the vase life and quality of cut roses and chrysanthemums. Journal of Plant Growth Regulation, n.0123456789, 2021. https://doi.org/10.1007/s00344021-10312-7 